\title{
有鉤骨鉤骨折の治療経験
}



\section{Fracture of the Hamate Hook}

by

Nobukazu Okimoto, Kinzo Yasuda, Meizo Akiyama,

Satoshi Nishida, Keiya Yamana, Masaya Takahashi

and Naoaki Kahara

Department of Orthopaedic Surgery, Okayama Rousai Hospital

This study reports on five cases of fracture of the hamate hook. The cases were classified by cause into three sport injuries (baseball, golf and tennis) and two accidents (fall and compression by rolling press).

Four cases were treated by excision of the hamate hook. Osteosynthesis with three threaded Kirschner wires and chip bone graft into the fractured site was performed on one case. Union was obtained with in four months after osteosynthesis. The clinical result was rated as good in all cases.

\section{はじめに}

近年，スポーツによる有鉤骨鉤骨折の報告は增えて いるが，手根骨骨折の中では稀であり，かつ，見逃さ れやすく，また解剖学的特徵により骨癒合しにくいと されている. 我々は最近 3 年間に, スポーツに起因す るもの 3 例, 外傷に起因するもの 2 例, 計 5 例を経験 し, いずれにも観血的治療法を行い良好な結果が得ら れた. 若干の文献的考察を加えて本骨折の問題点, 治 療法につき検討した。

\section{対象と方法}

症例は全て男性で年齢は 17 歳から 59 歳, 平均 35 歳. 受傷手は左手 4 例, 右手 1 例で, うち左利きは, 1 例であった。受傷機転は, ゴルフスイング, 野球で のバットスイング, 転倒, ローラーの圧挫による左手 それぞれの 1 例と, テニスラケット把持で疼痛が 4 ケ
月持続したあと右手を衝いて転倒した 1 例であった。 骨折型は Stark 分類法 ${ }^{4}$ によると, Proximal 1/3 が 4 例, Volar $1 / 3$ が 1 例であった（図 1 )。手術までの期 間は 1 日から 4 力月, 平均 2.3 力月であった。ゴルフ

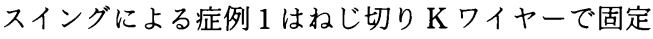
を行い，同時に骨移植も行った。他 4 例には骨片摘出 術を施行した（表 1 ).

\section{結果}

術後フォローアップ期間は 1.5 力月から 1 年 9 力 月, 平均 1 年であった. 全症例において, 術後握力は 健側の $90 \%$ 以上であり, 術前よりも握力低下したもの はなかった，手関節可動域，知覚とも正常であり，患 者さんの評価もすべて満足するものとなった.

症例

症例 1,42 歳, 男性, 左利き右打ち。平成 1 年 11 月 
表 1 有鉤骨鉤骨折症例

\begin{tabular}{|c|c|c|c|c|c|c|}
\hline 症例 & 年令- 性別 & 受傷側（利き手) & 受傷機転 & 手術までの期間 & 手 術 法 & 骨折型 \\
\hline 1 & 42 男 & 左 (右打ち) & ゴルフ & 1.5 ケ月 & 骨接合（骨移植） & $\mathrm{P} 1 / 3$ \\
\hline 2 & 17 男 & 左 (右打ち) & 野 球 & 4 力月 & 骨片摘出 & $\mathrm{P} 1 / 3$ \\
\hline 3 & 25 男 & 左 (右) & 打 撲 & 1日 & 骨片摘出 & V $1 / 3$ \\
\hline 4 & 59 男 & 左 (右) & 圧 挫 & 2 力月 & 骨片摘出 & $\mathrm{P} 1 / 3$ \\
\hline 5 & 30 男 & 右 (右) & テニス $\rightarrow$ 打撲 & 4 力月 & 骨片摘出 & $\mathrm{P} 1 / 3$ \\
\hline
\end{tabular}

8 日，ゴルフスイングにて誤って地面を強打した。そ の後, 左手関節痛出現. 11 月 18 日, 初診時, 手関節背 屈制限及び小指の知覚障害を認めた。単純レントゲン 手根骨 6 方向，斜位像にて鉤状突起骨折を認めた。手 根管撮影は疼痛のため肢位がとれなかった。CT 像に て鉤状突起基部での骨折を認めた。受傷後 1.5 ケ月半 経過した時点で手術を行った。骨片の転位は軽度であ

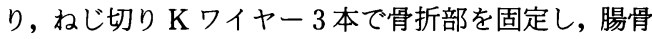
よりの海綿骨を骨折面につめ込んだ。術後 5 力月で抜 釘を行い,その後 1 カ月で完全にスポーツ復帰した(図 $2,3)$. 術後 1 年 9 ケ月の現在, 握力は健側 $38 \mathrm{~kg} に$ 対し患側 $40 \mathrm{~kg}$ であり,手関節可動域, 知覚も正常であ った.

症例 2,17 歳，男性，右投げ右打ち。平成 2 年 4 月 初め頃よりバットスイング時に左手関節尺側部痛を自 覚. 4 月末，ファウルチップの際，左手関節尺側に激 痛があった。 6 月 5 日, 当院初診時, 手関節掌背屈・ 尺屈制限, 環指・小指他動的過伸展テスト陽性, 及び 有鉤骨鉤に一致し，圧痛を認めた。単純レントゲン手 根骨 6 方向では骨折部がはっきりしなかったが，CT 像では鉤状突起基部での骨折を認めた（図 4 )。高校 3 年生でもあり夏までは野球を続けたいとの本人の希望 で， 2 力月間経過を見た後， 8 月 2 日骨片摘出術を施 行した.術後 1 年 2 力月の現在, 握力は健側 $58 \mathrm{~kg}$ に対 し患側 $60 \mathrm{~kg}$ であった。手関節可動域も正常であった。

\section{考察}

有鉤骨鉤は，手根管の尺側壁の形成，短小指屈筋・ 小指対立筋の起始，尺骨神経・動静脈の保護，グリッ プの補助に関与している゙．有鉤骨鉤骨折はグリップ 動作，あるいは，直接の打撲によって生じるといわれ ている。

本骨折の診断上の問題点は疼痛部位が限局しないこ とが多い点と通常の単純レントゲン撮影では骨折部が はっきりしない点である3445). そのため受傷機転をよ

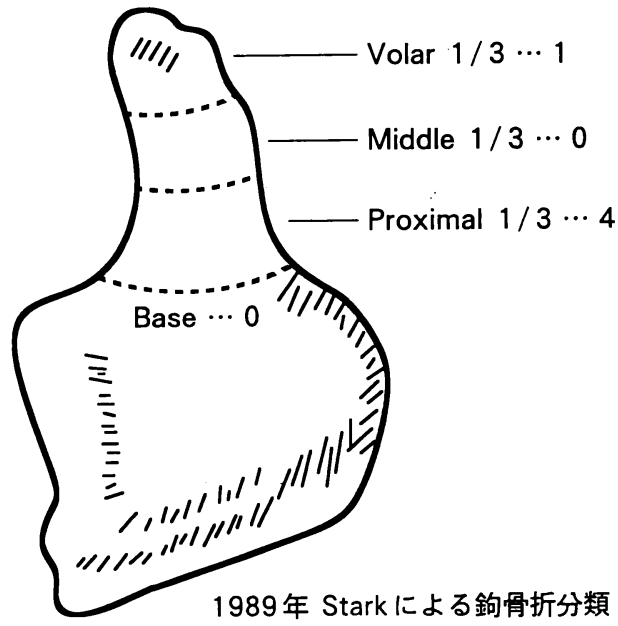

図 1 骨折の分類

く聴取した上で圧痛点を探すこと, 特にスポーツ歴, そのスポーツの特性, グリップ動作には留意しておく ことがポイントである。画像診断では斜位撮影，およ び, 手根管撮影, なかんずくCT を撮ることが肝要で ある. 自験例をみると手根管撮影では 5 例中 2 例が疼 痛のため撮影不能であったが， 3 例で骨折線が認めら れた.斜位撮影では 5 例中 4 例に骨折線が認められた。 撮影条件を工夫2)すれば斜位撮影法は患者にとって苦 痛もなく有用であると考えられた。CT 撮影は最も有 用であり，自験例では $2 \mathrm{~mm}$ スライスで全てに骨折線 が認められた。

次に治療法であるが，文献的には保存療法では骨瘜 合しにくく，尺骨神経障害や，届筋腱損傷を合併する こともあること, 観血的骨接合術では偽関節になり易 い点から骨片の摘出術が勧められている3(4)6). また, 握 力低下や若年者での鉤欠損の点から安易な骨片摘出術 を戒める意見も見られるが15)，今回，われわれは 5 症 例全てに最終的に観血的治療法を選択した，症例 1 は 

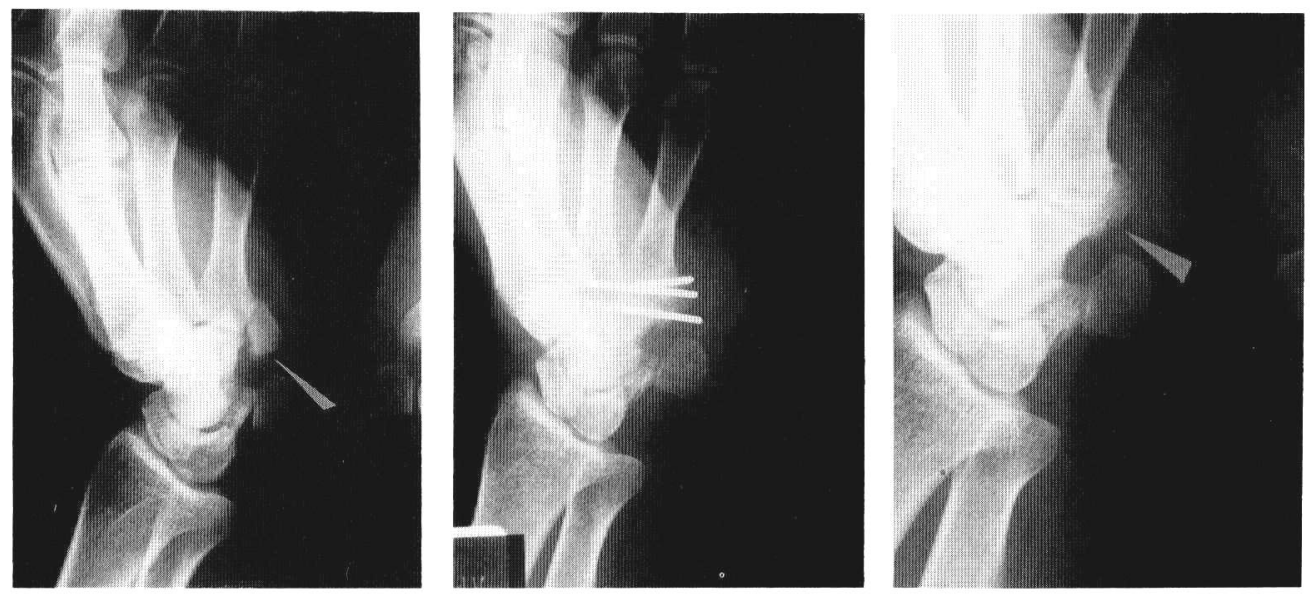

図 2 症例 142 歳 男性 骨接合術例

初馀時

矢印部に骨折 (Proximal 1/3) を認める

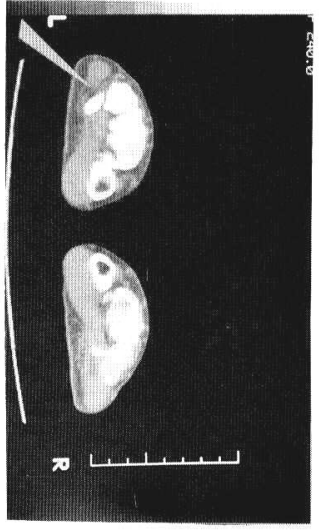

図3 症例 1 CT

術前 CT

矢印部に骨折 (Proximal 1/3)

を認める

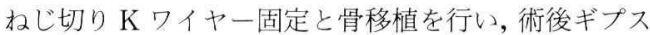
固定 6 週間と, その後 6 週間, 手関節装具を日中だけ 装用させ骨癒合が得られた。骨接合術は骨片の摘出に 比べて末梢骨片が小さく十分な固定が得がたいこと， 術後の固定期間が長くなること等の問題がある.

われわれの有銁骨鉤骨折に対する基本的治療方針 は，骨折レベルが鉤基部に近く，新鮮例で，かつ骨折 面の難開が強い症例では，骨接合術で対応できると考

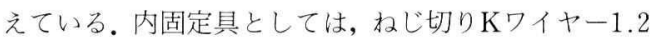

固定術後 1 万月

骨移植を併用し，ねじ切り $\mathrm{K}$

ワイヤー 3 本にて固定した
術後 9 ケ月

骨癒合を認める

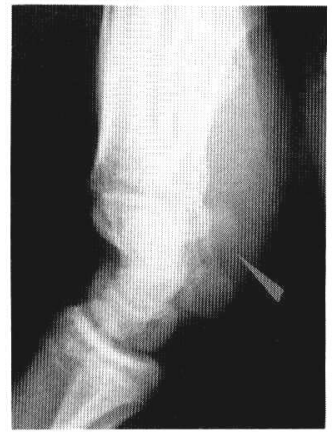

図4 症例 217 歳 男性 骨片摘出術例

術前 X-P

矢印部に骨折 (Proximal 1/3) を認める

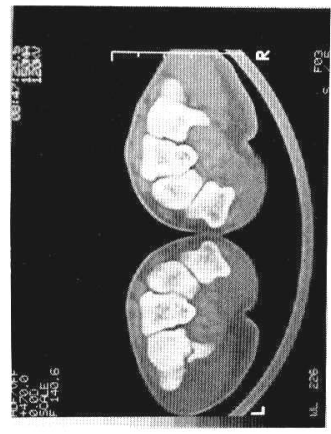

術前 CT

CTにても同様に骨折を 認める

$\mathrm{mm} \sim 1.5 \mathrm{~mm}$ 径のものを $2 \sim 3$ 本用いて固定して いる．末梢骨片が小さくHerbert screwよりも使い易 く, かつ $2 \sim 3$ 本用いられるので固定性も優れている と考えている，骨折面で難開の少ない骨折では外固定 を用い保存的に治療してみて, 経過により次の治療法 を選択してよいと考えている。陳旧例では，骨折レべ ルが，手掌に近いものは，摘出術の適応であろう。骨 片が小さく, かつ骨萎縮が進んでおり, 骨癒合を期待 できるほどの固定性を得ることは困難と考えている。 骨折レベルが鉤基部の骨折では，末梢骨片の骨萎縮が 
進んでいなければ，骨接合と骨移植の適応であろう。 固定性に問題ありと考えられれば摘出術を選択してい る. 安易に骨片摘出術を選択しないようにしている. 骨片摘出の際のポイントは手術時に, 骨折面をスムー ズにし, かつ小指球筋起始部を横手根靱帯に縫合して おくことが大切であると考えている，スポーツ復帰時 期の決定は, CT 像で骨瘜合を確かめてからにしてい る.

\section{結語}

1. 有鉤骨鉤骨折 5 例を経験し， 1 例に観血的整復 固定術を, 他 4 例には骨片摘出術を施行し良好な結果 を得た。

2. 本骨折は見逃しやすく受傷機転をよく考えた上 で圧痛点の検索と斜位撮影, 手根管撮影, CT どの補 助診断が有用である。

3. 治療方法としては, 新鮮例で, かつ骨折面の難 開が少なければ，まず保存的に加療してみる．離開が
強ければ骨接合術を選ぶ。陳旧例では観血的骨接合術 あるいは，骨片摘出術を行う．骨片の整復固定が容易 でないと考えられる骨折では，新鮮例，陳旧例ともに 骨片摘出術が第一選択であろう。

\section{参考文 献}

1）古川英樹ほか：手根部機能解剖. 整・災害 $34: 929$ 932, 1991 .

2) H. Jay Boulas. et al.: Hook of the Hamate Fractures. Orthopaedic Review. Vol, XIX, No.6, 518-529, 1990.

3）村上恒二ほか：有鈎骨鉤骨折. 臨床スポーツ医学 Vol. 8, 臨時增刊号 : 423-428, 1991.

4) Stark, H. H. et al.: Fracture of the hook of the hamate. JBJS. 71-A : 1202-1207, 1989.

5）隅田 潤ほか：有鉤骨鉤骨折に対しハーバートスク リニューで骨瘜合を試みた 3 例。骨折 $11: 190-192$, 1989.

6）田名部誠悦ほか：有鉤骨鉤骨折の 8 例. 整・災外 31 : 609-614, 1988. 